\title{
High expression of prolactin receptor is associated with cell survival in cervical cancer cells
}

\author{
Edgar I Lopez-Pulido', José F Muñoz-Valle², Susana Del Toro-Arreola² ${ }^{3}$ Luis F Jave-Suárez ${ }^{4}$, Miriam R Bueno-Topete ${ }^{5}$, \\ Ciro Estrada-Chávez ${ }^{6}$ and Ana Laura Pereira-Suárez ${ }^{3^{*}}$
}

\begin{abstract}
Background: The altered expression of prolactin (PRL) and its receptor (PRLR) has been implicated in breast and other types of cancer. There are few studies that have focused on the analysis of PRL/PRLR in cervical cancer where the development of neoplastic lesions is influenced by the variation of the hormonal status. The aim of this study was to evaluate the expression of PRL/PRLR and the effect of PRL treatment on cell proliferation and apoptosis in cervical cancer cell lines.
\end{abstract}

Results: High expression of multiple PRLR forms and PRLvariants of 60-80 kDa were observed in cervical cancer cell lines compared with non-tumorigenic keratinocytes evaluated by Western blot, immunofluorecence and real time PCR. Treatment with PRL $(200 \mathrm{ng} / \mathrm{ml})$ increased cell proliferation in HeLa cells determined by the MTT assay at day 3 and after 1 day a protective effect against etoposide induced apoptosis in HeLa, SiHa and C-33A cervical cancer cell lines analyzed by the TUNEL assay.

Conclusions: Our data suggests that PRL/PRLR signaling could act as an important survival factor for cervical cancer. The use of an effective PRL antagonist may provide a better therapeutic intervention in cervical cancer.

Keywords: Cervical cancer, PRLR, PRL, Proliferation, Apoptosis

\section{Background}

Prolactin (PRL) is a pituitary polypeptide hormone with multiple biological actions which include proliferation and differentiation of mammary gland cells, beginning and maintenance of lactation, immunoregulation, osmoregulation, behavior and reproduction [1]. The role of PRL in tumorigenesis was suggested some decades ago in breast cancer, mainly in animal-based research [2]. However, the relevance of extrapolating these results to humans has always been questioned. Epidemiological studies performed during the 80 s and 90 s were unable to reach unified conclusions from correlations between circulating PRL levels and risk for breast cancer [3,4]. Also, clinical studies report that reducing circulating PRL levels did not improve the condition of advanced breast cancer patients [5]. This controversial view of PRL in human cancer has been considerably modified in the past 10 years. Now, there is evidence

\footnotetext{
*Correspondence: analauraps@hotmail.com

${ }^{3}$ Laboratorio de Inmunología, Departamento de Fisiología, Centro Universitario de, Ciencias de la Salud, Universidad de Guadalajara, Guadalajara, México

Full list of author information is available at the end of the article
}

that high circulating PRL levels are considered a risk factor in breast cancer [6,7] and in other reproductive cancers such as endometrial, ovarian and prostate $[8,9]$. In addition to circulating PRL, there is clear evidence that several human tissues also express PRL like the mammary gland, prostate, skin, decidua, brain, some immune cells, adipocytes, and several others [10]. The biological effects of PRL are mediated by its interaction with the PRL receptor (PRLR). As PRLR is also expressed in these tissues, coexpression of both partners suggests the existence of an autocrine-paracrine loop of action. In recent years, reports supporting the tumor growth potency of local PRL in humans are emerging [11-14]. Alternative strategies involving PRLR neutralization and PRL antagonists opened new areas of research in this field.

PRLR belongs to the superfamily of hematopoietic cytokine receptors. Binding of PRL activates several signaling pathways, which include the Janus kinase-Signal transducer and activator of transcription (Jak-Stat), the Mitogen-activated protein kinases (MAPK), and the phosphoinositide 3 kinase (PI3K). Activation of these cascades results in endpoints such as differentiation, 
proliferation, survival, and secretion $[15,16]$. There are several prolactin receptor isoforms identified in humans, including the long form, an intermediate form, two short forms and soluble receptor isoforms, all of them generated through mRNA splicing [17-19]. Each of these forms has the same extra-cellular sequence, but differs in the intracellular signaling. The effects of PRL are dependent on the expressed PRLR form(s) of PRLR expression; the long and intermediate forms have been associated with increased cell proliferation or anti-apoptotic effects while the short and soluble forms have been described as being dominant negative [20]. Another mechanism potentially participating in local amplification of PRLR signaling in tumor contexts has recently emerged, and involves gain-of-function of PRLR variants.

Cervical cancer is a leading cause of morbidity and mortality among women worldwide, especially in developing countries [21]. Infection with oncogenic types of Human Papillomavirus (HPV) is an important factor in the development of cervical cancer [22]. Despite the evidence that HPV is strongly implicated as the causative agent of cervical cancer, this infection alone is not sufficient for tumor development. In addition, the immune system, as well as microbial, chemical $[23,24]$ and hormonal cofactors play a role in the development of neoplastic lesions in the uterine cervix. Indeed, the variation of the hormonal status depending on age, pregnancy or contraceptive use, has been shown to influence the development of cervical cancers [25-27]. PRL expression in tissues and serum has been found elevated in patients with cervical cancer [28,29] suggesting a possible participation in the development or progression of the disease. Hence, PRLR expression in cervical cancer has not been well documented and the roles of PRL and PRLR in tumor development are still unknown. In the present study, we determined the expression levels of PRL and PRLR and the effect of PRL treatment on cell proliferation and apoptosis in $\mathrm{HeLa}, \mathrm{SiHa}$ and $\mathrm{C}-33 \mathrm{~A}$ cervical cancer cell lines. In addition, we antagonized any possible effect of the locally produced PRL using specific blocking antibodies against PRL and PRLR.

\section{Methods}

\section{Standard culture conditions}

Cervical cancer cell lines (HeLa, SiHa, and C-33 A), as well as two human breast cancer cell lines (MCF-7, T-47D) and non-tumorigenic human keratinocytes ( $\mathrm{HaCaT}$ ) were obtained from the American Type Culture Collection (Rockville, MD); cells were cultured in a water-jacketed incubator at $37^{\circ} \mathrm{C}$ under an atmosphere of $95 \%$ air and $5 \%$ CO2 in RPMI 1640 or DMEM medium supplemented with $10 \%$ fetal bovine serum (FBS), L-glutamine (2 mM), penicillin $(100 \mathrm{U} / \mathrm{ml})$, streptomycin $(100 \mu \mathrm{g} / \mathrm{ml})$. Cell medium, FBS and antibiotics were obtained from Gibco (Carlsbad, CA).

\section{Western blotting}

Cells were seeded into 6-well plates and grown to $80 \%$ confluence in growth medium. Proteins were extracted from cell lines with $300 \mu \mathrm{l}$ of RIPA buffer (50 mM Tris, $150 \mathrm{mM}$ $\mathrm{NaCl}, 1 \% \mathrm{NP} 40,0.5 \%$ sodium deoxycholate, and $0.1 \%$ sodium dodecyl sulfate [SDS]), added with protease inhibitors (pestatin, leupeptin, aprotinin, quimostatin, antipain, and PMSF) and phosphatase inhibitors (Na3 VO4, and $\mathrm{NAF}$ ), and clarified by centrifugation at $4^{\circ} \mathrm{C}$ for $20 \mathrm{~min}$. Protein concentration was determined by the Lowry method (DC Protein Assay, Bio-Rad). Forty micrograms of total protein were mixed with loading buffer, resolved on a $7.5-12 \%$ SDS- polyacrylamide gels under denaturing conditions and electro-transferred to polyvinylidene difluoride membranes (Bio-Rad, CA). Nonspecific binding was blocked with $5 \%$ milk and $1 \%$ bovine serum albumin solution. Then, membranes were incubated at $4^{\circ} \mathrm{C}$ overnight with primary antibodies (diluted 1:1000 for PRLR (H-300 Santa Cruz Biotechnology), 1:500 for PRL (E-9 Santa Cruz Biotechnology) and 1:10000 for Actin (MAB1501 Millipore), HRP-conjugated antirabbit or anti-mouse secondary antibody (Santa Cruz Biotechnology) (diluted 1:5000) was used to reveal the immune detection and blots were developed with a chemiluminescence system (Immobilion, Millipore). As an internal control to confirm that similar amounts of protein were loaded for each lane, actin levels were determined. Optical density measurements were determined and analyzed using Image J analysis software (NIH).

\section{Fluorescent immunocytochemistry}

Cells were grown to $80 \%$ confluence on 8-well glass chamber slides cover slips (Labtek, Nalgene) in growth medium. Then, cells were fixed with $4 \%$ pararaformaldehide for 10 min at $-20^{\circ} \mathrm{C}$. Slides were blocked for $90 \mathrm{~min}$ with bovine serum albumin (BSA) at room temperature, permeabilized with $.2 \%$ Tween-20 and then incubated overnight at $4{ }^{\circ} \mathrm{C}$ with primary antibody diluted 1:50. Next, they were incubated with secondary anti-mouse or anti-rabbit antibodies coupled to Alexa Fluor 488 (Invitrogen) diluted 1:1000 for $1 \mathrm{~h}$. Cell nuclei were counterstained using $1 \mu \mathrm{g} / \mathrm{ml}$ of 4',6-diamidino-2-phenylindole dihydrochloride (DAPI) (Invitrogen). The fluorescent staining pattern was evaluated using an Axio Imager 2 fluorescence microscope (Carl Zeiss, Göttingen, Germany).

\section{Total RNA isolation and real-time PCR}

Total RNA was isolated using TRIzol reagent (Invitrogen, Carlsbad, CA) according to the manufacturer's instructions, spectrophotometric quantification at 260, 280 and $230 \mathrm{~nm}$ was realized using a NanoDrop 1000 Spectrophotometer (Thermo Fisher Scientific, Inc.). Retrotranscription using $1 \mu \mathrm{g}$ of total RNA was achieved using M-MLV reverse transcriptase and random primers following the recommended 
Invitrogen protocol. The real-time PCR reaction was performed using an LightCycler Nano Real-Time PCR System (Roche Diagnostics) starting with a $10 \mathrm{~min}$ incubation at $95^{\circ} \mathrm{C}$ followed by 40 cycles $\left(95^{\circ} \mathrm{C}\right.$ for $15 \mathrm{sec}$ and $60^{\circ} \mathrm{C}$ for $1 \mathrm{~min})$. The PCR reaction mixture $20 \mu \mathrm{l}$ consisted of: $2 \mu \mathrm{l}$ of cDNA template (100 ng), $1 \mu$ of 20X TaqMan probes (Applied Biosystems) PRLR (Hs01061477_m1 FAM labeled) or PRL (Hs01062137_m1 FAM labeled) specific, 10 $\mu \mathrm{l}$ of 2X TaqMan Gene Expression Master Mix (Applied Biosystems) and $7 \mu \mathrm{l}$ of RNase-free water. PRL and PRLR mRNA relative expression was calculated using the 2$\Delta \Delta \mathrm{Cq}$ method after validating similar reaction efficiencies of both the interest gene (PRL and PRLR) and the reference gene 18s RNA (Hs03928985_g1 VIC labeled, Applied Biosystems) by running serial dilutions of both genes [30].

\section{Cell proliferation assay (MTTAssay)}

Cells $\left(5 \times 10^{3}\right)$ were seeded in 96-well plates and were allowed to grow for $24 \mathrm{~h}$ in growth medium. Growth medium was replaced with serum free medium supplemented with $10 \%$ charcoal striped serum (CSS) before dosing with PRL 200ng/ml (L7009 Sigma), PRLR neutralizing antibody (MAB1167 R\&D systems) or PRL antibody (6F11 QED Bioscience) for 3 or 5 days. Then $5 \mu \mathrm{l}$ of 3-(4,5-dimetylthiazol-2-yl)-2,5-diphenyl-tetrazolium reagent $(\mathrm{MTT})(5 \mathrm{mg} / \mathrm{ml})$ was added to cells and the cultures and incubated for $3 \mathrm{~h}$ at $37^{\circ} \mathrm{C}$ in a $\mathrm{CO} 2$ chamber. Blue formazan crystals were solubilized with acidified isopropanol, and formazan levels were determined by measuring absorbance at $570 \mathrm{~nm}$ in an Epoch Microplate Spectrophotometer (Bio-Tek Instruments, Inc.).

\section{Apoptotic assay (TUNEL Assay)}

For the TUNEL Assay we used the kit APO-BrdU (Invitrogen). Cells were grown for $24 \mathrm{~h}$ in 8 -well chamber slides seeded with $5 \times 10^{4}$ cells per well were treated and incubated with etoposide alone and in the presence of PRL or PRL antibody for 24 hours at $37^{\circ} \mathrm{C}$. The slides were washed in PBS and fixed with 4\% paraformaldehyde for 30 min at room temperature. Fixed cells were washed in PBS, permeabilized with $.2 \%$ Tween- 20 for $10 \mathrm{~min}$ on ice, and then incubated with terminal deoxynucleotidyl transferase and BrdUTP for $1 \mathrm{~h}$ at $37^{\circ} \mathrm{C}$. After rinsing with PBS, slides were treated with Alexa Fluor 488 dye-labeled anti-BrdU antibody at $37^{\circ} \mathrm{C}$ for $30 \mathrm{~min}$ and mounted with a glass coverslip. Staining of DNA fragmentation was observed under ultraviolet fluorescent microscope (Carl Zeiss) counting at least 200 cells/well.

\section{Statistical analysis}

Data was analyzed using Graph pad PRISM software (Graph pad version 5.01). Significant effects were determined using ANOVA followed by Student's t-test, including Dunnett's post-test for multiple comparisons against a single control group. A statistically significant difference was considered to be present at $\mathrm{p}<0.05$.

\section{Results}

\section{PRLR is highly expressed in cervical cancer cells}

PRLR expression was assessed in cervical cancer cell lines (HeLa, SiHa and C-33A) and human nontumorigenic keratinocytes ( $\mathrm{HaCaT}$ ) by western blot, immunocitochemistry and real time-PCR. Breast cancer cell lines T-47D and MCF-7 served as the positive control. To detect PRLR expression we used an antibody raised against amino acids 323-622 of human PRLR that recognized multiple isoforms. In T-47D and MCF-7 we observed a high expression of different bands $(110 \mathrm{kDa}, 90 \mathrm{kDa}, 80 \mathrm{kDa}, 60 \mathrm{kDa}$ and $50 \mathrm{kDa})$ that corresponded to PRLR isoforms. Differently than breast cancer cells, in cervical cancer cell lines HeLa, $\mathrm{SiHa}$ and C-33A we detected three of the PRLR forms $(110 \mathrm{kDa}, 60 \mathrm{kDa}$ and $50 \mathrm{kDa})$. However, human nontumorigenic keratinocytes $(\mathrm{HaCaT})$ only expressed low levels of the $50 \mathrm{kDa}$ PRLR band (Figure 1A). The optical density measurements from immunoblots demonstrated higher PRLR expression in cancer cell lines in comparison with the non-tumorigenic $\mathrm{HaCaT}$ cell line (Figure 1B).

Next, we observed the localization of PRLR by immunofluorescence. The intensity of fluorescence was augmented in cancer cell lines compared with $\mathrm{HaCaT}$, which correlates with western blot results. PRLR staining was heterogeneous on the cell surface and in the cytoplasm of all cancer cells lines (Figure 1C). To evaluate relative mRNA expression levels of PRLR we did real time PCR using a specific probe that could detect all PRLR isoforms. As can be seen, the PRLR mRNA detectable in all cervical cancer cell lines was augmented in comparison with $\mathrm{HaCaT}$ that expressed about 15 to 60 fold decrease (Figure 1D). Cell lines T47-D and MCF-7 showed the highest PRLR expression.

\section{Autocrine Prolactin is produced in cervical cancer cells}

PRL expression was detected using the same techniques to evaluate PRLR expression. Our results reveal that cervical, breast cancer and $\mathrm{HaCaT}$ cells express PRLlike proteins. Interestingly, PRL found in all cell lines had a higher molecular weight about $60-80 \mathrm{kDa}$ (Figure 2A). The optical density measurements from western immunoblots showed augmented PRL expression in cervical cancer cell lines in comparison with the non-tumorigenic $\mathrm{HaCaT}$ cell line (Figure 2B). A similar localization of PRL was observed in all cells studied, the intensity of fluorescence was augmented in T47-D, MCF-7 and HeLa (Figure 2C). The mRNA levels were increased in cancer cells compared with HaCat (Figure 2D). 
A)

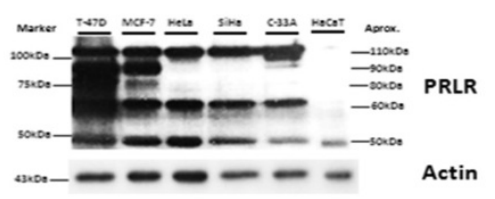

B)

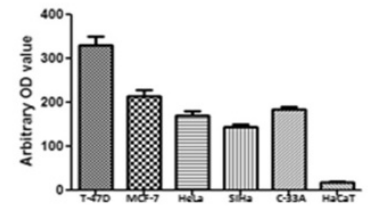

D)

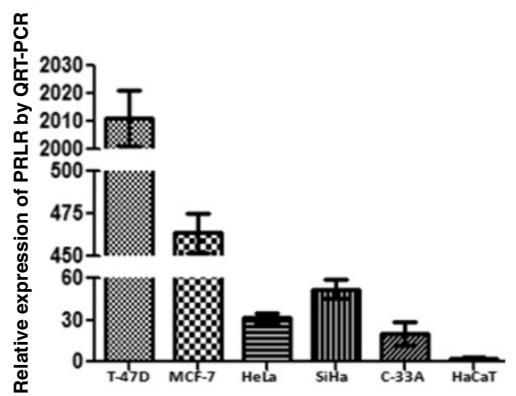

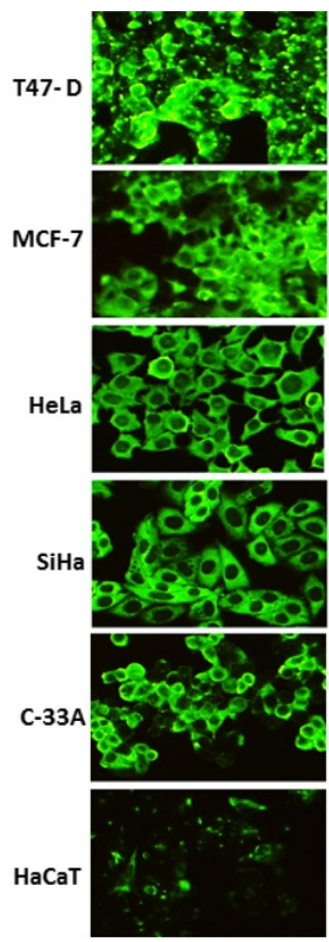

PRLR

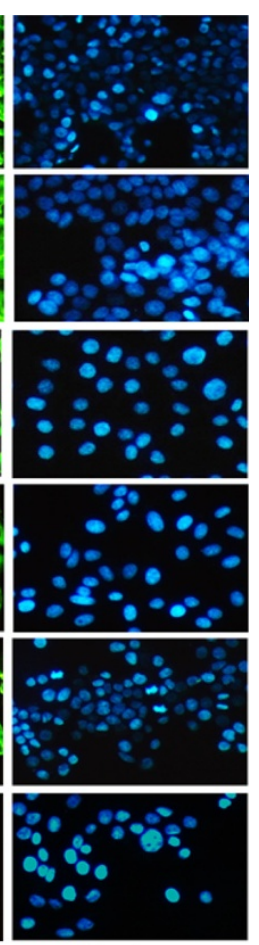

Nucleus

Figure 1 PRLR expression in human cervical cancer cells. SiHa, C-33A, HeLa (Cervical cancer cells) and control cells MCF-7, T-47D (breast cancer), HaCaT (Inmortalized human keratinocytes) were cultured in DMEM or RPMI medium containing 10\% FBS. A) PRLR protein was determined by western blot using a specific antibody against the PRLR, PRLR proteins were identified by their size. B) Demonstration of the arbitrary optical density measurements from Western immunoblots assessing PRLR levels. C) The cells grown on coverslips were fixed, and the localization of PRLR (green) was observed by inmunocitochemistry using a secondary antibody conjugated with Alexa fluor 488 and DAPI stain (blue) to visualize the presence of cells. Magnification 10 x. D) Relative expression of PRLR mRNA was measure by quantitative RT-PCR.

Effects of prolactin and PRL/PRLR blocking antibodies on cell proliferation in cervical cancer cells

To test whether PRL had an effect on the proliferation in cervical cancer cells, we cultured cells in the absence and presence of PRL, PRLR-AB or PRL-AB for 3 and 5 days. Treatment with PRL (200 $\mathrm{ng} / \mathrm{ml})$ increased the viable cell number in HeLa about 9\% after 3 days of incubation (Figure 3A); while no effect was observed in SiHa and C33A (Figure 3B, C). The incubation with PRLR-AB $(2.5 \mu \mathrm{g})$ or PRL-AB $(200 \mathrm{ng} / \mathrm{ml})$ had not impact over the total cell number in cervical cancer cells. Similar dose response analyzes with PRL and blocking antibodies were performed in breast cancer and HaCat cells, observing an increase of $6 \%$ in the cell number of T47-D after 3 days of incubation with PRL. Moreover, the treatment with PRL and PRLR antibodies decreased the total cell number in a range of $5-8 \%$ in T47-D and $12-18 \%$ in MCF-7 at day 3 (Figure 3D, E). But, this decrease was statistically significant only in MCF-7 after 3 days of incubation with the PRL-AB. No effect on cell proliferation in HaCat cells was observed (Figure 3F). Other dose and time conditions were used in all the cell lines and no significant difference was detected in the total cell number (data not shown).
Prolactin treatment reduce DNA fragmentation induced by etoposide

Treatment with etoposide $(1 \mu \mathrm{M})$ augmented the number of cells with fragmented DNA in all cell lines after $24 \mathrm{~h}$ of incubation, as expected. PRL (200 ng/ml) costimulus significantly decreased the number of cells with DNA fragmentation from 27.3 to $19.1 \%$ in HeLa cells, from 26.7 to $21.2 \%$ in SiHa cells and from 22.1 to $16.4 \%$ in C-33A (Figure 4A, B, C). Also, PRL treatment decreased induced cell death in breast cancer cells, from 28.7 to $18.3 \%$ in T47-D cells and from 30.6 to $21 \%$ in MCF-7 cells (Figure 4D, E). PRL had no effect on cell survival in $\mathrm{HaCat}$ cells pretreated with etoposide (Figure 4F). PRL-AB treatment $(200 \mathrm{ng} / \mathrm{ml})$ did not modify apoptosis induced by etoposide in any of the cell lines tested. Also, no effect on DNA fragmentation was found when PRL-AB or PRL was used.

\section{Discussion}

To date, several reports associate the expression of the PRL/PRLR with the development and progression of cancers such as breast, prostate, colorectal, gynecological, laryngeal, and hepatocellular [31]. There are few reports 

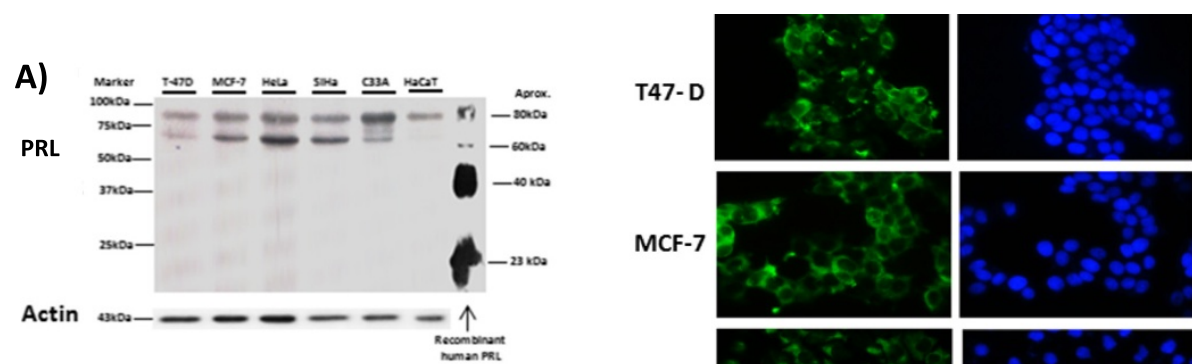

B)
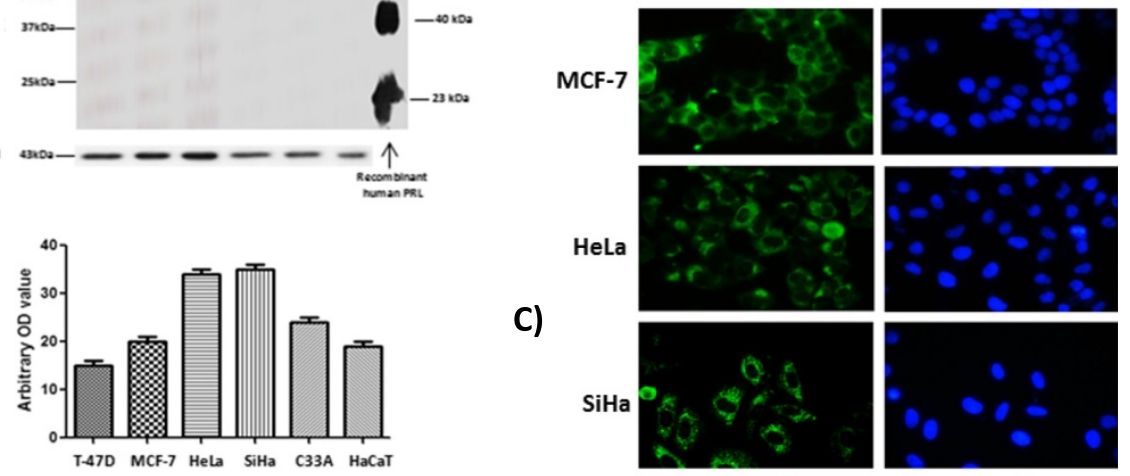

D)

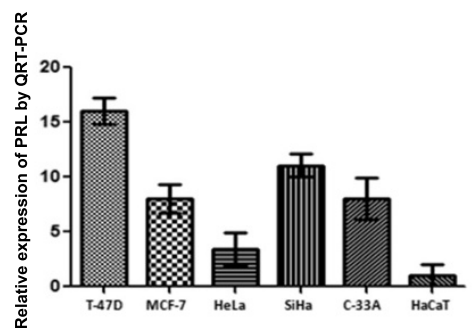

C)
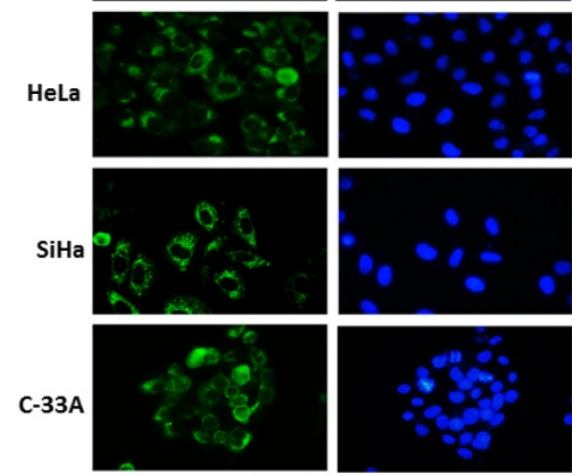

$\mathrm{HaCaT}$

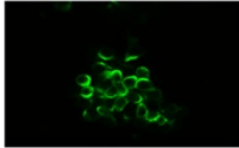

PRL

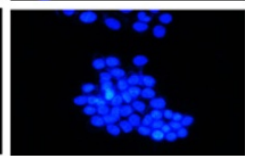

Nucleus

Figure 2 Presence of autocrine PRL in human cervical cancer cell lines. SiHa, C-33A, HeLa (Cervical cancer cells) and control cells MCF-7, T-47D (breast cancer), HaCaT (Inmortalized human keratinocytes) were cultured in DMEM or RPMI medium containing 10\% FBS. A) PRL protein was determined by western blot using a specific antibody against PRL. B) Demonstration of the arbitrary optical density measurements from Western immunoblots assessing PRL levels. C) The cells grown on coverslips were fixed, and the localization of PRL (green) was observed by inmunocitochemistry using a secondary antibody conjugated with Alexa fluor 488 and DAPI stain (blue) to visualize the presence of cells. Magnification $40 \times$. D) Relative expression of PRL mRNA was measure by quantitative RT-PCR.

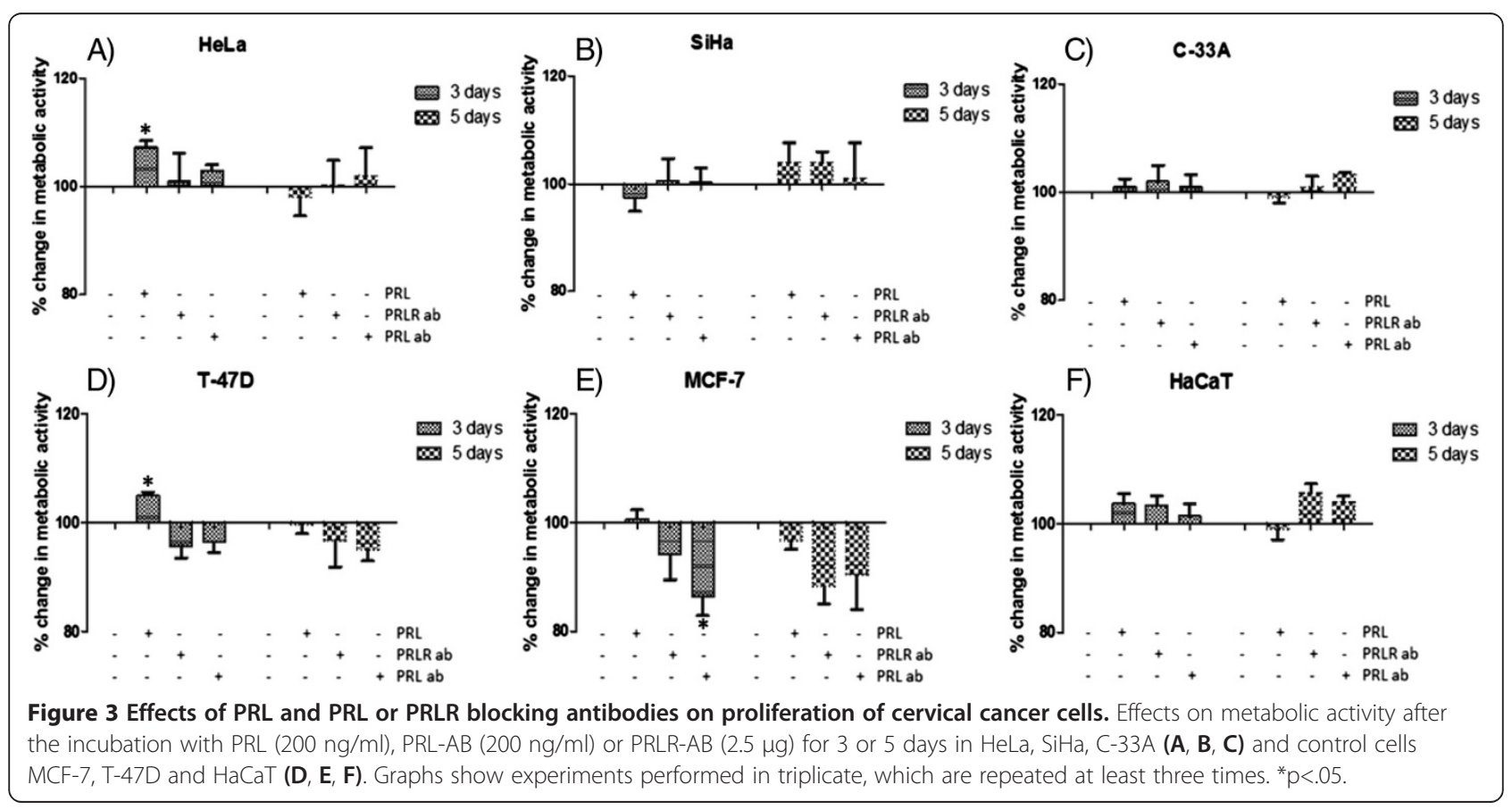




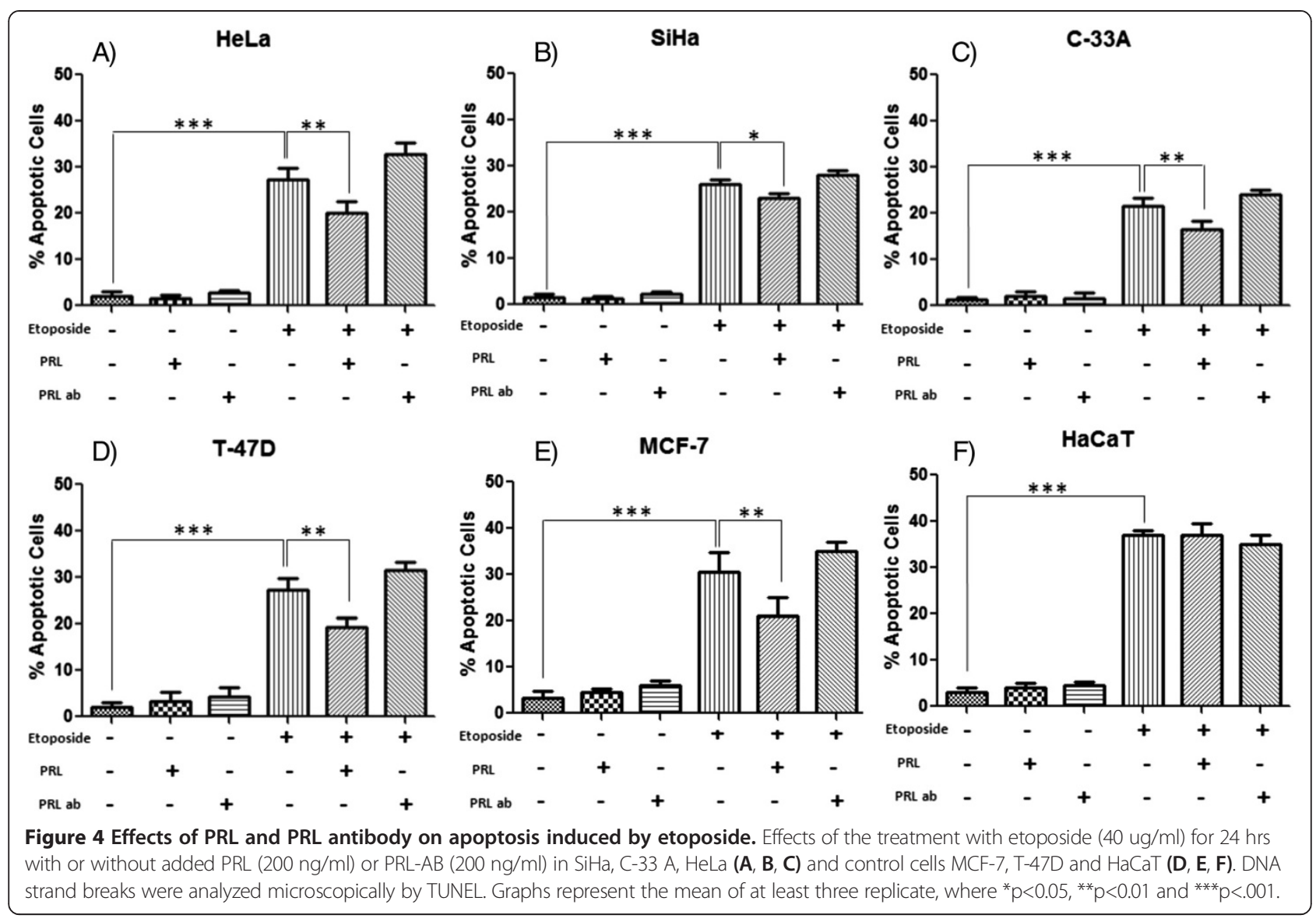

that have focused on the analysis of the PRL or PRLR expression and its possible role in cervical cancer remains unknown. A previous study demonstrates that the presence of PRL was augmented in malignant cervix tissues [28]. In another work, they reported an increment of serum PRL levels in a considerable number of patients with cervical cancer [29]. In a recent study of our investigation group we observed an increased PRLR expression in cervical cancer samples compared with intraepithelial cervical lesions (data not published). With this background information, we decided to evaluate the expression levels of PRL and PRLR and their possible participation in cell survival of cervical cancer cell lines.

The results of this study demonstrate that PRLR are over-expressed at protein and mRNA levels in human cervical cancer cells compared with human non-tumorigenic keratinocytes. Heterogeneous PRLR staining was observed on the cell surface and in the cytoplasm. Previous reports have proposed a mechanism by which PRLR might become stabilized and accumulated in breast cancers. The proposed mechanism states a constitutive oncogenic signaling downstream of the Ras pathway which inactivates Glycogen synthase kinase 3 beta and prevents phosphorylation of PRLR on Ser349 and PRLR ubiquitination, ultimately leading to PRLR stabilization $[32,33]$.
Moreover, when we evaluated PRLR expression in protein extracts from the cervical cancer cell lines, we observed a high expression of $110 \mathrm{kDa}, 60 \mathrm{kDa}$ and 50 $\mathrm{kDa}$ bands that could correspond to different PRLR variants previously reported [17-19]. While, in $\mathrm{HaCaT}$ cells, only a $50 \mathrm{kDa}$ band was detected. Actually, several investigators have focused in revealing the impact of the expression of specific PRLR isoforms. They have described that short PRLR forms act as dominant negative regulators of the stimulatory actions of the long PRLR forms in vitro. In prostate cancer, it has also been demonstrated that the long term increased expression of the PRLR short form $1 \mathrm{~b}$ in PC-3 human prostate cancer cells decreases cell growth and migration, and causes multiple changes in gene expression consistent with reduced invasive capacity [34]. Another report showed a low ratio of short to long PRLR forms in breast cancer tumors when compared with normal samples; this reduced expression in patients with cancer could contribute to breast tumor development and progression [20]. The expression of multiple PRLR products (that might correspond to long and short PRLR forms) observed in cervical cancer cells lines suggests that the specific evaluation of the PRLR isoforms could be important for the diagnosis or treatment of the disease. 
Furthermore, we showed an autocrine PRL synthesis in cervical cancer cells through the PRL transcript and protein. PRL found in the cell lysates had a higher molecular weight $(60-80 \mathrm{kDa})$ than the PRL peptide of 23 $\mathrm{kDa}$ commonly reported. This data is consistent with a previous report that demonstrated the presence of a $60 \mathrm{kDa}$ PRL-like variant in both normal and systemic lupus erythematosus (SLE) PBMNC extracts, preferentially expressed in SLE subjects [35]. This PRL variant could be generated by post-translational modifications such as glycosylation or phosphorylation [36,37].

PRL and PRLR co-expression observed in cervical cancer cells suggests the existence of an autocrine-paracrine loop of action supporting the cell growth in cervical cancer. The results of this study showed that PRL treatment had significant effects only on HeLa cell proliferation, yet these effects were not observed in C-33A or SiHa. This observed difference in response between cervical cancer cells could be due to the origin of the cells. Since SiHa and C-33A are derived from a cervical squamous cell carcinoma, HeLa cell line is derived from cervical adenocarcinoma. Cervical adenocarcinoma arises within glands located in the endocervix, and it is well documented that this kind of tumor has an amplified hormonal response.

Although the major association of PRL with human cancer is given in breast cancer [6,38]; the role of PRL in the proliferation of classical breast cancer cell lines is controversial. Some authors have reported that PRL promotes cell proliferation in some breast cancer cell lines [39]. In contrast, other investigators showed that PRL had no effect on cell proliferation in human breast cancer cell lines MDA-MB-231, T-47D, MCF-7 and Hs578T [40]. The disparity in the results can be influenced by the use of different culture techniques and conditions including the use of different clones of each cell line. One more study, also reported that PRL treatment had no effect on proliferation of LNCaP and PC3 prostate cancer cell lines but showed that PRL has a pro-apoptotic effect in the androgen responsive cell line LNCaP [41].

Several studies have demonstrated that breast cancer and others cell lines like ovarian cancer cells produce autocrine PRL, and that the incubation with PRL antibodies and other PRLR antagonists reduce the cell number [42-44]. In our experiments, we did not find an effect over the proliferation of the cervical cancer cells using PRL or PRLR antibodies, yet a decrease in the number of cells after treatment can be appreciated in the MCF-7 and T47-D cell lines previously reported.

However, we did find that treatment with PRL had a protective effect against cell death induced by etoposide, decreasing the number of apoptotic cells in all the cervical cancer cell lines. Similar results were obtained in T-47D and MCF-7, but not in $\mathrm{HaCaT}$ cells. This suggests that PRL has an important role in the cell survival of cervical and breast cancer. A similar result has been reported in breast cancer cell lines T-47D, MCF-7 and Hs578T, showing that PRL has the ability to prevent breast cancer cells from undergoing apoptosis after the treatment with $\mathrm{C} 2-$ ceramide [40].

At signaling level, it has been reported that even if Jak2 is essential for the proliferative effects of PRL in the onset of induced mammary tumorigenesis, the deletion of Jak2 following neoplastic transformation had no significant impact on the survival and growth of mammary cancer cells in culture and in vivo [45]. We cannot exclude that PRLR signaling is still capable of promoting breast cancer progression and invasion through Jak2/Stat5-independent pathways such as c-Src, FAK, and MAP kinases and beyond towards proliferative effects; thus, other PLR roles are currently being diligently investigated. PRL could favor cell motility and confer resistance to chemotherapy, and thereby contribute to metastasis dissemination $[6,46]$; such diverse effects may be mediated by distinct PRLR signaling cascades.

\section{Conclusions}

In summary, we demonstrated that human cervical cancer cell lines HeLa, SiHa and C33A over-expressed multiple PRLR forms, and also produced autocrine PRL-like proteins. In addition, PRL augmented cell proliferation in HeLa cells and had a protective effect against etoposide induced apoptosis in HeLa, SiHa and C-33A, suggesting that PRL/PRLR signaling could act as an important survival factor for cervical cancer. Our data supports the hypothesis that the use of an effective PRL antagonist may provide a better therapeutic intervention in cervical cancer. More studies are necessary to determine the signaling pathways activated by PRL and could support the transformation mechanisms activated in those cell lines and hence in cervical cancer.

\section{Competing interests \\ The authors declare that they have no competing interests.}

\section{Authors' contributions}

ELP performed all the experimental work described in the study he searched for scientific literature, and contributed with figures. LFJS and MBT contributed with apoptosis experiments and Real Time PCR. JFMV and CEC contributed with scientific ideas and research. STA participated in the study design and contributed to the review of the manuscript. APS conceived and designed the theoretical framework of the study as well as provided scientific guidance throughout the project and wrote the manuscript. All authors read and approved the final manuscript.

\section{Acknowledgements}

This work was supported by grant from the Consejo Nacional de Ciencia y Tecnología, Convocatoria 2007, Fondo SEP-CONACyT (79709) and PROMEP UdG-PTC-605.

\section{Author details}

Doctorado en Ciencias Biomédicas, Centro Universitario de Ciencias de la Salud, Universidad de Guadalajara, Guadalajara, Jalisco, México. ${ }^{2}$ Grupo de Inmunogenética Funcional, Departamento de Biología Molecular y Genómica, Centro Universitario de Ciencias de la Salud, Universidad de 
Guadalajara, Guadalajara, Jalisco, México. 'ªboratorio de Inmunología, Departamento de Fisiología, Centro Universitario de, Ciencias de la Salud, Universidad de Guadalajara, Guadalajara, México. ${ }^{4}$ División de Inmunología, Centro Médico Nacional de Occidente (CMNO), Instituto Mexicano del Seguro Social(IMSS), Guadalajara, Jalisco, México. ${ }^{5}$ Instituto de Enfermedades Crónico-Degenerativas, Departamento de Biología Molecular y, Genómica, Centro Universitario de Ciencias de la Salud, Universidad de Guadalajara, Guadalajara, Jalisco, México. ${ }^{6}$ Unidad de Biotecnología Médica y Farmacéutica, Centro de Investigación y Asistencia en, Tecnología y Diseño del Estado de Jalisco AC, Guadalajara, Jalisco, México.

Received: 15 July 2013 Accepted: 11 October 2013

Published: 22 October 2013

\section{References}

1. Goffin V, Binart N, Touraine P, Kelly PA: Prolactin: the new biology of an old hormone. Annu Rev Physiol 2002, 64:47-67.

2. Welsch CW, Nagasawa H: Prolactin and murine mammary tumorigenesis: a review. Cancer Res 1977, 37(4):951-963.

3. Clevenger CV, Furth PA, Hankinson SE, Schuler LA: The role of prolactin in mammary carcinoma. Endocr Rev 2003, 24(1):1-27.

4. Tworoger SS, Hankinson SE: Prolactin and breast cancer etiology: an epidemiologic perspective. Journal J Mammary Gland Biol Neoplasia 2008 , 13(1):41-53.

5. Bonneterre J, Mauriac L, Weber B, Roche H, Fargeot P, Tubiana-Hulin M, Sevin M, Chollet P, Cappelaere P: Tamoxifen plus bromocriptine versus tamoxifen plus placebo in advanced breast cancer: results of a double blind multicentre clinical trial. Eur J Cancer Clin Oncol 1988, 24(12):1851-1853.

6. Hankinson SE, Willett WC, Michaud DS, Manson JE, Colditz GA, Longcope C, Rosner B, Speizer FE: Plasma prolactin levels and subsequent risk of breast cancer in postmenopausal women. J Natl Cancer Inst 1999, 91(7):629-634.

7. Tworoger SS, Hankinson SE: Prolactin and breast cancer risk. Cancer Lett 2006, 243(2):160-169

8. Stattin P, Rinaldi S, Stenman UH, Riboli E, Hallmans G, Bergh A, Kaaks R Plasma prolactin and prostate cancer risk: A prospective study. Int $J$ Cancer 2001, 92(3):463-465.

9. Levina W, Nolen B, Su Y, Godwin AK, Fishman D, Liu J, Mor G, Maxwell LG, Herberman RB, Szczepanski MJ, et al: Biological significance of prolactin in gynecologic cancers. Cancer Res 2009, 69(12):5226-5233.

10. Ben-Jonathan N, Mershon JL, Allen DL, Steinmetz RW: Extrapituitary prolactin: distribution, regulation, functions, and clinical aspects. Endocr Rev 1996, 17(6):639-669.

11. Mertani HC, Garcia-Caballero T, Lambert A, Gerard F, Palayer C, Boutin JM, Vonderhaar BK, Waters MJ, Lobie PE, Morel G: Cellular expression of growth hormone and prolactin receptors in human breast disorders. Int J Cancer 1998, 79(2):202-211.

12. Touraine P, Martini JF, Zafrani B, Durand JC, Labaille F, Malet C, Nicolas A, Trivin C, Postel-Vinay MC, Kuttenn F, et al: Increased expression of prolactin receptor gene assessed by quantitative polymerase chain reaction in human breast tumors versus normal breast tissues. J Clin Endocrinol Metab 1998, 83(2):667-674.

13. Leav I, Merk FB, Lee KF, Loda M, Mandoki M, McNeal JE, Ho SM: Prolactin receptor expression in the developing human prostate and in hyperplastic, dysplastic, and neoplastic lesions. Am J Pathol 1999, 154(3):863-870.

14. Gill S, Peston D, Vonderhaar BK, Shousha S: Expression of prolactin receptors in normal, benign, and malignant breast tissue: an immunohistological study. J Clin Pathol 2001, 54(12):956-960.

15. Kossiakoff AA: The structural basis for biological signaling, regulation, and specificity in the growth hormone-prolactin system of hormones and receptors. Adv Protein Chem 2004, 68:147-169.

16. Goffin V, Kelly PA: The prolactin/growth hormone receptor family: structure/ function relationships. J Mammary Gland Biol Neoplasia 1997, 2(1):7-17.

17. Kline JB, Roehrs $\mathrm{H}$, Clevenger CV: Functional characterization of the intermediate isoform of the human prolactin receptor. J Biol Chem 1999, 274(50):35461-35468.

18. Hu ZZ, Meng J, Dufau ML: Isolation and characterization of two novel forms of the human prolactin receptor generated by alternative splicing of a newly identified exon 11. J Biol Chem 2001, 276(44):41086-41094.
19. Trott JF, Hovey RC, Koduri S, Vonderhaar BK: Alternative splicing to exon 11 of human prolactin receptor gene results in multiple isoforms including a secreted prolactin-binding protein. J Mol Endocrinol 2003, 30(1):31-47.

20. Meng J, Tsai-Morris CH, Dufau ML: Human prolactin receptor variants in breast cancer: low ratio of short forms to the long-form human prolactin receptor associated with mammary carcinoma. Cancer Res 2004, 64(16):5677-5682.

21. Mohar A, Frias-Mendivil M: Epidemiology of cervical cancer. Cancer Invest 2000, 18(6):584-590.

22. Bosch FX, Manos MM, Munoz N, Sherman M, Jansen AM, Peto J, Schiffman MH, Moreno V, Kurman R, Shah KV: Prevalence of human papillomavirus in cervical cancer: a worldwide perspective. International biological study on cervical cancer (IBSCC) study group. J Natl Cancer Inst 1995, 87(11):796-802.

23. De Vet HC, Van Leeuwen FE: Dietary guidelines for cancer prevention: the etiology of a confused debate. Nutr Cancer 1986, 8(4):223-229.

24. Tindle RW: Immune evasion in human papillomavirus-associated cervical cancer. Nat Rev Cancer 2002, 2(1):59-65.

25. Brisson J, Morin C, Fortier M, Roy M, Bouchard C, Leclerc J, Christen A, Guimont C, Penault F, Meisels A: Risk factors for cervical intraepithelial neoplasia: differences between low- and high-grade lesions. Am J Epidemiol 1994, 140(8):700-710.

26. Moreno V, Bosch FX, Munoz N, Meijer CJ, Shah KV, Walboomers JM, Herrero $\mathrm{R}$, Franceschi S: Effect of oral contraceptives on risk of cervical cancer in women with human papillomavirus infection: the IARC multicentric case-control study. Lancet 2002, 359(9312):1085-1092.

27. Munoz N, Franceschi S, Bosetti C, Moreno V, Herrero R, Smith JS, Shah KV, Meijer CJ, Bosch FX: Role of parity and human papillomavirus in cervical cancer: the IARC multicentric case-control study. Lancet 2002. 359(9312):1093-1101.

28. Macfee MS, McQueen J, Strayer DE: Immunocytochemical localization of prolactin in carcinoma of the cervix. Gynecol Oncol 1987, 26(3):314-318.

29. Hsu CT, Yu MH, Lee CY, Jong HL, Yeh MY: Ectopic production of prolactin in uterine cervical carcinoma. Gynecol Oncol 1992, 44(2):166-171.

30. Livak KJ, Schmittgen TD: Analysis of relative gene expression data using real-time quantitative PCR and the $2(-$ Delta Delta $C(T)$ ) method. Methods 2001, 25(4):402-408.30

31. Sethi BK, Chanukya GV, Nagesh VS: Prolactin and cancer: Has the orphan finally found a home? Indian J Endocrinol Metab 2012, 16(Suppl 2):S195-S198.

32. Plotnikov A, Varghese B, Tran TH, Liu C, Rui H, Fuchs SY: Impaired turnover of prolactin receptor contributes to transformation of human breast cells. Cancer Res 2009, 69(7):3165-3172.

33. Plotnikov A, Li Y, Tran TH, Tang W, Palazzo JP, Rui H, Fuchs SY: Oncogene-mediated inhibition of glycogen synthase kinase 3 beta impairs degradation of prolactin receptor. Cancer Res 2008, 68(5):1354-1361.

34. Huang KT, Walker AM: Long term increased expression of the short form $1 \mathrm{~b}$ prolactin receptor in $\mathrm{PC}-3$ human prostate cancer cells decreases cell growth and migration, and causes multiple changes in gene expression consistent with reduced invasive capacity. Prostate 2010, 70(1):37-47.

35. Larrea F, Martinez-Castillo A, Cabrera V, Alcocer-Varela J, Queipo G, Carino C, Alarcon-Segovia D: A bioactive 60-kilodalton prolactin species is preferentially secreted in cultures of mitogen-stimulated and nonstimulated peripheral blood mononuclear cells from subjects with systemic lupus erythematosus. J Clin Endocrinol Metab 1997, 82(11):3664-3669.

36. Sinha YN: Structural variants of prolactin: occurrence and physiological significance. Endocr Rev 1995, 16(3):354-369.

37. Bollengier F, Mahler A, Braet C, Claeyssens M, Vanhaelst L: Glycosylated rat prolactin: isolation and structural characterization. Arch Physiol Biochem 2001, 109(2):180-190.

38. Wang DY, De Stavola BL, Bulbrook RD, Allen DS, Kwa HG, Verstraeten AA, Moore JW, Fentiman IS, Hayward JL, Gravelle IH: The permanent effect of reproductive events on blood prolactin levels and its relation to breast cancer risk: a population study of postmenopausal women. Eur J Cancer Clin Oncol 1988, 24(7):1225-1231.

39. Fuh $G$, Wells JA: Prolactin receptor antagonists that inhibit the growth of breast cancer cell lines. J Biol Chem 1995, 270(22):13133-13137.

40. Perks CM, Keith AJ, Goodhew KL, Savage PB, Winters ZE, Holly JM: Prolactin acts as a potent survival factor for human breast cancer cell lines. $\mathrm{Br} J$ Cancer 2004, 91(2):305-311

41. Giuffrida D, Perdichizzi A, Giuffrida MC, La Vignera S, D'Agata R, Vicari E, Calogero AE: Does prolactin induce apoptosis? Evidences in a prostate cancer in vitro model. J Endocrinol Invest 2010, 33(5):313-317. 
42. Ginsburg E, Vonderhaar BK: Prolactin synthesis and secretion by human breast cancer cells. Cancer Res 1995, 55(12):2591-2595.

43. Fields K, Kulig E, Lloyd RV: Detection of prolactin messenger RNA in mammary and other normal and neoplastic tissues by polymerase chain reaction. Lab Invest 1993, 68(3):354-360

44. Tan D, Chen KE, Khoo T, Walker AM: Prolactin increases survival and migration of ovarian cancer cells: importance of prolactin receptor type and therapeutic potential of S179D and G129R receptor antagonists. Cancer Lett 2011, 310(1):101-108.

45. Sakamoto K, Triplett AA, Schuler LA, Wagner KU: Janus kinase 2 is required for the initiation but not maintenance of prolactin-induced mammary cancer. Oncogene 2010, 29(39):5359-5369.

46. LaPensee EW, Ben-Jonathan N: Novel roles of prolactin and estrogens in breast cancer: resistance to chemotherapy. Endocr Relat Cancer 2010, 17(2):R91-R107.

doi:10.1186/1475-2867-13-103

Cite this article as: Lopez-Pulido et al:: High expression of prolactin receptor is associated with cell survival in cervical cancer cells. Cancer Cell International 2013 13:103.

\section{Submit your next manuscript to BioMed Central and take full advantage of:}

- Convenient online submission

- Thorough peer review

- No space constraints or color figure charges

- Immediate publication on acceptance

- Inclusion in PubMed, CAS, Scopus and Google Scholar

- Research which is freely available for redistribution 